\author{
Ірина Щербак, \\ кандидат педагогічних наук, \\ викладач кафедри інформатики \\ Комунального закладу «Харківська гуманітарно- \\ педагогічна академія» Харківської обласної ради, \\ (м. Харків, Україна)

\section{Iryna Shcherbak,} \\ PhD of Pedagogical Sciences, \\ lecturer at the Department of Informatics \\ Municipal Establishment «Kharkiv Humanitarian- \\ Pedagogical Academy» of Kharkiv Regional Council \\ (Kharkiv, Ukraine) \\ irinasherbak19920626@gmail.com \\ ORCID ID 0000-0003-4161-735X
}

УДК 378.014.25:303.424]:001.4(045)

\title{
ОГЛЯД МЕТОДИК СТРАТЕГІЙ ПОЗИЦІОНУВАННЯ ПРОВІДНИХ УНІВЕРСИТЕТІВ У МІЖНАРОДНОМУ ІНФОРМАЦІЙНОМУ ПРОСТОРІ
}

Анотація. У статті дано визначення поняття «стратегії позиціонування» та розглянуто конкретні розробки методик стратегій позиціонування провідних університетів у міжнародному інформаційному просторі науковцями.

У науковому дослідженні автор розглянула розробки методик стратегій позиціонування підприємств з точки зору різних науковців. Ці розробки доцільно застосовувати для розробок стратегій позиціонування провідних університетів у міжнародному інформаційному просторі. Важливими методологічними аспектами $є$ аналіз системи позиціонування ЗВО як інструмента впливу на різні сфери суспільства (політичну, економічну, соціальну та культурну сфери життєдіяльності тощо).

На сучасному етапірозвитку країн $€$ безліч методик підвищення конкурентоспроможності, а саме: модель Бостонської консультативної групи; модель М. Портера; метод «Мак-Кінзі»; модель Shell/DPM; метод LOTS; метод PIMS; ситуаційний аналіз (SWOT-аналіз); метод експертного оцінювання; модель Хофера/Шенделя; фінансовоекономічний метод; метод картування стратегічних груп та інші.

Ключові слова: стратегія, стратегія позиціонування, методика розробки стратегій, заклад вищої освіти.

\section{OVERVIEW OF METHODS OF POSITIONING STRATEGIES FOR LEADING UNIVERSITIES IN THE INTERNATIONAL INFORMATION SPACE}

Abstract. The article defines the concept of "positioning strategy" and discusses the specific development of methods for positioning strategies of leading universities in the international information space by scientists. Researchers determine the choice of parameters by which positioning is carried out, not paying attention to the number of parameters. But, according to the author, this is undoubtedly an important factor, without which methodologies somewhat reduce their value. Selecting more parameters indicators improves the quality of the study, although it requires more time and energy.

Having analyzed the classifications examined in the article, the researcher identified several determinant attributes (quantitative and qualitative). It is these signs, in his opinion, that demonstrate the effectiveness of positioning strategies of leading universities in the international information space.

In a scientific study, the author examined the development of techniques for positioning strategies of enterprises from the point of view of various scientists. It is advisable to use these developments for developing strategies for positioning leading universities in the international information space. Important methodological aspects are the analysis of the positioning system of a higher educational institution as an instrument of influence on various spheres of society (political, economic, social and cultural spheres of life, etc.).

After analyzing the psychological, pedagogical and specialized literature, the author came to the conclusion that at the present stage of the development of countries, there are many methods to increase competitiveness, namely: the model of the Boston advisory group; model of M. Porter; McKinsey method; Shell / DPM model LOTS method; PIMS method situational analysis (SWOT analysis); expert assessment method; Hofer / Shendel model; the financial and economic method, the method of mapping strategic groups and others.

The conducted study makes it possible to assert that the main directions of the strategy for positioning HEI in the IIS in the management process are aimed at helping: identification and representation of specific features of the institution / educational service / educational product; implementation of the mission, goals, directions; analysis of consumer assessment 
of educational services of the university and its competitors; determination of the current state of positioning of HEl and prospects for its development; maintaining and expanding the results achieved.

Keywords: strategy, positioning strategy, strategy development methodology, higher education institution.

\section{ВСТУП}

Постановка проблеми. За умов розвитку ринкових відносин на українському ринку професійної освіти, входження університетів України у світовий освітній простір у рамках Болонського процесу, швидкого поширення відкритої онлайн освіти конкуренція освітніх організацій за студентів зростає. Глобалізація освіти стає основою для створення альянсів між вишами з різних країн, а інтернаціоналізація освітніх послуг, активізація і підвищення результативності науково-дослідної діяльності допомагають українським університетам посідати гідну позицію у світових і національних рейтингах. Водночас залишається проблема відтоку талановитої молоді, перспективних учених до країн з більш високим рівнем життя. Для українських освітніх організацій професійної освіти, щоб витримати конкуренцію за вітчизняного та іноземного абітурієнта, стає актуальним не тільки вища якість освіти і наукових досліджень, а й формування привабливого образу, бренду, підтримання позитивної репутації в суспільстві, реалізація клієнт-орієнтованого маркетингового підходу і розроблення стратегії позиціонування з урахуванням очікувань і потреб студентів, споживачів освітніх послуг.

Українська система реформування вищої освіти створюється в умовах жорсткої конкуренції вищих навчальних закладів, у режимі виживання на ринку освітніх послуг. Ситуація на ринку послуг вищої професійної освіти вимагає комплексного підходу до управління освітніми послугами українських ЗВО в умовах формування загальноєвропейського освітнього простору (Харківська А. А., 2013).

Університети і професійні освітні організації змушені здійснювати і вдосконалювати маркетингову діяльність, приділяючи більшу увагу управлінню власним брендом, формуванню та оцінюванню своєї позиції на світовому, українському та регіональному ринках професійної освіти. У зв'язку з цим є практична потреба в серйозних теоретичних пошуках у галузі позиціонування і управління брендом освітніх організацій на ринку професійної освіти.

Аналіз наукових досліджень і публікацій. Розробці методик аналізу стратегій позиціонування провідних університетів у міжнародному інформаційному просторі присвячені роботи таких авторів як Б. Адамсона, М. Брея, О. Зозульова, Н. Куденка, М. Мейсона, А. Наливайка, Н. Писаренка, Б. Фоміна, Г. Хулея.

\section{МЕТА І ЗАВДАННЯ ДОСЛІДЖЕННЯ}

Метою статті $€$ проаналізувати методики аналізу стратегій позиціонування провідних університетів у міжнародному інформаційному просторі.

\section{МЕТОДИ ДОСЛІДЖЕННЯ}

Для досягнення поставлених у статті цілей використано загальні й спеціальні методи наукового дослідження: системний і проблемно-цільовий аналіз філософської, науково-педагогічної, спеціальної літератури, нормативно-правових документів, ресурсів мережі Інтернет.

\section{РЕЗУЛЬТАТИ ДОСЛІДЖЕННЯ}

Мета статті зумовила розглянути розробки методик аналізу стратегій позиціонування провідних університетів у міжнародному інформаційному просторі, які спираються на системні, стратегічні, синергетичні, соціальномаркетингові, критеріально-комплексні та системно-методичні методологічні підходи.

Відповідно до цього, спочатку дамо визначення поняття «стратегії позиціонування» та розглянемо конкретні розробки цього процесу науковцями.

Стратегія позиціонування - це план дій, який необхідно реалізувати щоб відокремити власну брендову продукцію від продукції конкурентів та створити її позитивний імідж у свідомості споживача послуг.

На думку М. Брея, Б. Адамсона, М. Мейсона(Mark Bray, Bob Adamson, Mark Mason Comparative, 2007), у порівняльно-педагогічному дослідженні особливо важливою ідеєю є багаторівневий аналіз, який наочно представлений у кубі Брейя й Томаса. Як стверджують автори, для отримання багатогранної і цілісної оцінки освітніх явищ їх необхідно розглядати щонайменше в трьох вимірах. На передній грані куба представлено географічні рівні для порівняння (регіони світу / континенти, країни, штати / провінції, округи, школи, класи і конкретні люди), на верхній межі - нелокалізовані демографічні групи (етнічні, вікові, релігійні, тендерні), на бічній грані - аспекти освіти та суспільства (навчальні програми, методика навчання, фінансування, управління, політичні зміни, ринки праці). Названі рівні взаємопов'язані і взаємозумовлені, тому ігнорування хоча б одного з них істотно знижує якість проведених порівняньу галузі освіти. Твердження науковців, що досліджуване нами явище потребує багаторівневого аналізу, не викликає жодних сумнівів. У зв'язку з цим продовжимо аналіз відповідних праць.

Проаналізувавши психолого-педагогічну та спеціальну літературу, ми виявили, що на сучасному етапірозвитку країн є безліч методик підвищення конкурентоспроможності, зокрема: модель Бостонської консультативної групи; модель М. Портера; метод «Мак-Кінзі»; модель Shell/DPM; метод LOTS; метод PIMS; ситуаційний аналіз (SWOTаналіз); метод експертного оцінювання; модель Хофера/Шенделя; фінансово-економічний метод; метод картування стратегічних груп та інші.

Наступною розглянемо розробку стратегії позиціонування Г. Хулея. Дослідник вважає доцільним здійснювати за трьома фазами розробку стратегій та їх аналіз (Хулей Г. Дж., 2002):

1. Визначення поточної позиції - включає: 1) формування переліку конкурентів, 2) визначення характеристик відповідних товарів, 3) оцінку відповідної значущості атрибутів, 4) детермінацію позицій конкуруючих товарів 
щодо найважливіших атрибутів, 5) ідентифікацію потреб покупців, 6) комплексний підхід за всіма вищезгаданими пунктами;

2. Вибір бажаної позиції: 1) визначення цільового ринку (отже, кола ймовірних конкурентів); 2) ідентифікація конкурентних переваг або відмінностей від конкурентів.

3. Розробка стратегії для досягнення бажаної позиції. Стратегія позиціонування залежить від вибору цільового ринку і створення комплексної пропозиції для залучення і задоволення цього (цільового) ринку краще, аніж конкуренти. Після визначення поточної позиції і спрямованості її розвитку розглядаються кілька основних стратегічних альтернатив: 1) зміцнення наявних позицій; 2) поступове репозиціонування; 3) радикальне репозиціонування; 4) витіснення конкурентів із займаної позиції.

Більшість науковців вважають за необхідним виокремити головні параметри стратегії, які при розробці методики аналізу стратегії позиціонування, залишились не розкриті у роботі Г. Хулея.

О. Зозульов та Н. Писаренко запропонували подібний алгоритм стратегій позиціонування. Вони виділяють такі етапи:

1. Вибір параметрів, за якими буде проводитися позиціонування, визначення їх важливості для цільової аудиторії.

2. Визначення релевантних фірм, їхніх товарів і марок, які належать до цього сегмента.

3. Проведення порівняльного аналізу марок-конкурентів.

4. Аналіз схем позиціонування і вибір критерію позиціонування.

5. Визначення стратегії позиціонування. На основі аналізу схем позиціонування компанії необхідно визначитися зі стратегією позиціонування.

6. Вибір типу позиціонування марки. На цьому етапі необхідно визначитися з типом позиціонування марки на ринку, тобто яким чином компанія буде впроваджувати свою марку у свідомість цільових споживачів.

7. Реалізація позиціонування у загальній системі маркетингових стратегій (Зозульов О.В., Писаренко Н.Л., 2004).

На першому етапі методики позиціонування, О. Зозульов та Н. Писаренко, окреслюють вибір параметрів, за якими проводиться позиціонування, не звертаючи уваги на кількість параметрів. Але, на нашу думку, це $є$ безсумнівно важливим фактором, без якого дана методологія дещо знижує свою цінність. Вибір більшої кількості параметрів показників підвищує якість дослідження, хоча й потребує більше часу та енергії.

Б. Фомін, у своїй методиці, визначає шість основних напрямів позиціонування розвитку підприємства: стратегічна конкурентна позиція розрахована на оптимізацію прибутковості фірми в найближчій перспективі (1 рік); виробнича позиція виражає відношення до проблеми собівартості продукції та трудомісткості виробництва; виробнича та конкурентна позиції разом характеризують можливості та зобов'язання за гарантіями прибутковості від реалізації товарів та послуг підприємства на освоєних ринках; інноваційна позиція визначає тематику НДДКР (науково-дослідних та дослідно-конструкторських робіт) і проектів з упровадження нової продукції, нових технологій, нововведень в маркетингу та менеджменті на всьому інноваційному полі підприємства за всіма обсягами його стратегічних зон господарювання; підприємницька позиція встановлює на тривалий термін умови досягнення прибутковості, економічної та фінансової стабільності за рахунок балансування стратегічних зон господарювання, оптимального використання активів, ефективного планування стратегічних ресурсів, урахування інтересів клієнтів, стратегічних партнерів та груп впливу; адміністративна позиція говорить про готовність, активність та відкритість всього персоналу й вищого керівництва підприємства до стратегічних змін та ефективного забезпечення конкурентної, виробничої, конкурентної та виробничої, інноваційної та підприємницької складових стратегії розвитку бізнесу підприємства й підвищення його конкурентоздатності (Фомин Б. В., 2009).

Методика аналізу ефективності стратегії підприємства за А. Наливайко, яка описана в монографії «Теорії стратегії підприємства. Сучасний стан та напрямки розвитку» включає в себе (Наливайко А. П., 2001):

- визначення критеріїв ключового фактору успіху;

- встановлення їх відносного значення та ранжування;

- оцінку рівня оволодіння ключовими факторами успіху підприємства його конкурентами;

- зведення одержаної оцінки до загального результату.

За монографією «Маркетингові стратегії фірми» Н. Куденка, класифікація маркетингових стратегій позиціонування підприємств, базується на:

- характері позиціонування (конкурентне та споживче позиціонування);

- факторі (показнику) позиціонування (за показниками якості товару; за співвідношенням «ціна-якість»; за сферою застосування товару; за відмінними особливостями споживачів товарів; за низькою ціною; за сервісним обслуговуванням; за позитивними особливостями технології; за іміджем фірми);

- кількості факторів (показників) позиціонування (за однією; двома або за трьома ознаками), «стратегія позиціонування за однією ознакою використовується на ранніх стадіях життєвого циклу товару, коли рівень конкуренції ще не надто великий. 3 розвитком ринку та посиленням конкуренції актуальності набувають стратегії позиціонування за двома та трьома ознаками» і «якщо позиціонування здійснюється більш ніж за трьома ознаками, то воно є неефективним, оскільки не відкарбовується у свідомості споживача» (Куденко Н. В., 2002, С. 169);

- на визначенні помилок позиціонування (недостатнє; надмірне; змішане або сумнівне позиціонування) (Куденко Н. В., 2002, С. 169). 
Проаналізувавши цю класифікацію, ми можемо визначити декілька детермінантних ознак (кількісних та якісних). Саме ці ознаки, на нашу думку, демонструють ефективність стратегій позиціонування провідних університетів у міжнародному інформаційному просторі.

На думку А. Харківської, стратегії позиціонування спрямовані на доведення до цільового ринку компанії концепції позиціонування. Це забезпечується всією її діяльністю на ринку, інструментами якої є сукупність елементів маркетингової операційної стратегії.

Ефективність позиціонування визначається тим, наскільки успішно були вирішені завдання цієї стратегії, тобто тим, чи досягнуті цілі ринкової організації (Харківська А. А., 2018).

\section{ВИСНОВКИ ТА ПЕРСПЕКТИВИ ПОДАЛЬШИХ ДОСЛІДЖЕНЬ}

Отже, основні напрями стратегії позиціонування ЗВО в МІП в процесі управління спрямовані на допомогу: ідентифікації та репрезентації специфічних ознак закладу освіти/освітньої послуги/освітнього продукту; реалізації місії, цілей, напрямів; аналізу оцінки споживачами освітніх послуг університету та його конкурентів; визначенню сучасного стану позиціонування ЗВО та перспектив його розвитку; збереженню та розширенню досягнутих результатів.

\section{СПИСОК ВИКОРИСТАНИХ ДЖЕРЕЛ}

Mark Bray, Bob Adamson, Mark Mason Comparative. (2007). Education Research: Approaches and Methods. Hong Kong: Comparative Education Research Centre (CERC), Springer, 2007. 444 p.

Хулей Г. Дж. (2002). Позиціонування. В кн. Маркетинг. Бізнес-клас: енциклопедія / Під ред. М. Бейкера / Перекл. з англ. під ред. Л.Волкової, С.Божук, Т.Маслової, Л.Ковалик, Н.Розової. Санкт-Петербург: Пітер, 2002. С. 394-402.

Зозульов О.В., Писаренко Н.Л. (2004). Ринкове позиціонування: з чого починається створення успішних брендів. Київ: Знання-Прес.

Фомин Б. В. (2009). Основные тезисы концепции стратегического менеджмента Предприятия. URL: www.uran.donetsk.ua/masters/2009/fem/yefimova/librery/article5.htm (дата звернення: 02.05.2020).

Наливайко А. П. (2001). Теорія стратегії підприємства. Сучасний стан та напрямки розвитку: монографія. Київ: КНЕУ.

Куденко Н. В. (2002). Маркетингові стратегії фірми: монографія. Київ: КНЕУ.

Харківська А. А. (2018). Стратегія позиціонування закладу вищої освіти: від управління витратами до управління результатами. Актуальні питання гуманітарних наук. 2018. Вип. 22(2). С.133-137 URL: http://journals.uran.ua/index.php/2308-4855/article/ view/166984 (дата звернення: 02.05.2020).

Харківська А. А. (2013). Управління інноваційним розвитком ВНЗ в умовах формування загальноєвропейського простору вищої освіти. Теорія та методика управління освітою: фах. видання. № 13. С. 4-12.

\section{REFERENCES}

Mark Bray, Bob Adamson, \& Mark Mason Comparative (2007). Education Research: Approaches and Methods. Hong Kong: Comparative Education Research Centre (CERC), Springer.

Khulei H. Dzh. (2002). Pozytsionuvannia. Marketynh. Biznes-klas: entsyklopediia / Pid red. M. Beikera / Perekl. z anhl. pid red. L.Volkovoi, S.Bozhuk, T.Maslovoi, L.Kovalyk, N.Rozovoi. Sankt-Peterburh: Piter, 394-402.

Zozulov O.V., \& Pysarenko N.L. (2004). Rynkove pozytsionuvannia: z choho pochynaietsia stvorennia uspishnykh brendiv. Kyiv: Znannia-Pres.

Fomyn B. V. (2009). Osnovnыe tezysы kontseptsyy stratehycheskoho menedzhmenta Predpryiatyia. URL: www.uran.donetsk.ua/-masters/2009/ fem/yefimova/librery/article5.htm (data zvernennia: 02.05.2020).

Nalyvaiko A. P. (2001). Teoriia stratehii pidpryiemstva. Suchasnyi stan ta napriamky rozvytku: monohrafiia. Kyiv: KNEU.

Kudenko N. V. (2002). Marketynhovi stratehii firmy: monohrafiia. Kyiv: KNEU.

Kharkivska A. A. (2018). Stratehiia pozytsionuvannia zakladu vyshchoi osvity: vid upravlinnia vytratamy do upravlinnia rezultatamy. Aktualni pytannia humanitarnykh nauk, 22(2), 133-137. URL: http://journals.uran.ua/index.php/2308-4855/article/view/166984 (data zvernennia: 02.05.2020).

Kharkivska A. A. (2013). Upravlinnia innovatsiinym rozvytkom VNZ v umovakh formuvannia zahalnoievropeiskoho prostoru vyshchoi osvity. Teoriia ta metodyka upravlinnia osvitoiu: fakh. Vydannia, 13, 4-12. 